\title{
UPAYA MENINGKATKAN HASIL BELAJAR IPA DENGAN MENGGUNAKAN KOMBINASI MEDIA DIORAMA DAN MEDIA GAMBAR PADA SDN 5 LANGKAI PALANGKARAYA TAHUN PELAJARAN 2015/2016
}

\author{
Oleh \\ Normilasari, Purna Haidawati
}

\begin{abstract}
ABSTRAK
Penelitian ini, bertujuan untuk mengetahui (1) Aktivitas peserta didik terhadap penggunaan kombinasi media diorama dan media gambar dalam pembelajara IPA (2) Untuk mengetahui peningkatan hasil belajar IPA setelah menggunakan kombinasi media diorama dan media gambar.

Metode yang digunakan penelitian adalah menggunakan rancangan Penelitian Tindakan Kelas (PTK) yang berusaha memecahkan atau menjawab masalah yang dihadapi pada saat situasi sekarang. Teknik Pengumpulan data dalam penelitian ini adalah tes dan observasi. Teknik analisis data dalam penelitian ini menggunakan rumus persentase ketuntasan klasikal individual.

Berdasarkan hasil penelitian menunjukkan bahwa : (1). Peserta didik lebih aktif dan menyenangkan pada saat pembelajaran IPA dengan menggunakan kombinasi media diorama dan media gambar. Pada Siklus I, aktivitas peserta didik memperoleh skor ratarata 2,71 dengan kriteria cukup. Pada Siklus II, skor rata-rata aktivitas yang diperoleh peserta didik adalah 3,78dengan criteria baik. (2). Ada peningkatan hasil belajar IPA peserta didik pada saat pembelajaran IPA dengan menggunakan kombinasi media diorama dan media gambar. Hal ini terlihat dari hasil belajar peserta didik sebelum dilaksanakannya penelitian tindakan kelas dan sesudah dilaksakannya penelitian tindakan kelas. Pada tes awal, hasil belajar peserta didik memperoleh nilai rata-rata 59,52 (dibawah nilai $\mathrm{KKM} \geq 65$ ) dengan ketuntasan klasikal 28,57\% dengan kriteria sangat tidak tercapai. Pada Siklus I hasil belajar peserta didik memperoleh nilai rata-rata 64,76 dengan ketuntasan klasikal 42,86\% dengan kriteria kurang tercapai. Siklus II hasil belajar peserta didik memperoleh nilai rata-rata 88,57 dengan ketuntasan klasikal 100\% dengan kriteria sangat tercapai.
\end{abstract}

(C) Universitas Muhammadiyah Palangkaraya

\section{Kata Kunci: Aktivitas dan Hasil Belajar IPA}

\section{PENDAHULUAN}

Penggunaan media dalam proses pembelajaran sangat membantu tujuan pembelajaran yang diberikan,sehingga lebih mudah dipahami dan dimengerti oleh peserta didik. Penggunan media yang di buat oleh guru atau menggunakan kombinasi media diorama dan media gambar tentunya akan lebih menarik minat belajar dan menyenangkan dalam mempelajari pelajaran IPA.

Peserta didik dapat melihat langsung apa yang dipelajarinya di buku dan tidak hanya membayangkannya saja. Peran guru sangat penting dalam 
mencapai hasil belajar maksimal peserta didik. Dalam hal ini guru harus mampu memilih model pembelajaran yang baik dan tepat, agar sesuai dengan konsep materi pelajaran yang akan disampaikan dalam pembelajaran IPA yang tentunya bersifat baik, kreatif, aktif, menarik dan menyenangkan sehingga peserta didik bersemangat dan minat pada mata pelajaran IPA.

Hasil observasi yang peneliti lakukan bulan oktober dikelas IV SDN 5 Langkai Palangka Raya bahwa masih rendahnya hasil belajar peserta didik untuk mata pelajaran IPA, disebabkan metode pembelajaran yang kurang bervariasi, dalam proses pembelajaran tidak menggunakan media pembelajaran sebagai alat bantu dalam proses pelaksanaan belajar mengajar dikelas, sehingga berdampak terhadap peserta didik yang cenderung bosan dalam penyampaian materi pembelajaran IPA, dengan tidak menggunakan media pembelajaran dalam proses belajar mengajar didalam kelas. Konsep dan tujuan dalam materi pembelajaran yang disampaikan sulit untuk dipahami dan dimengerti oleh peserta didik dan kurangnya keaktifan peserta didik pada saat pembelajaran IPA.

Hasil belajar peserta didik yang dicapai sesuai KKM masih rendah. Permasalahan tersebut juga diperkuat dengan data kuantitatif yang diperoleh dari hasil evaluasi pembelajaran IPA, sebagian peserta didik kelas IV SDN 5 Langkai peserta didik yang mampu mencapai KKM hanya 7 orang peserta didik (25\%) dari 21 orang peserta didik. KKM yang distandarkan oleh sekolah pada mata pelajaran IPA yaitu 65 .
Dari beberapa permasalahan yang dijelaskan peneliti tersebut, terlihat bahwa keterampilan guru, aktivitas peserta didik dan hasil belajar IPA kurang maksimal, akibatnya perlu adanya peningkatan kualitas pembelajaran IPA di SDN 5 Langkai. Berdasarkan permasalahan tersebut, guru diharapkan mampu menciptakan suatu pembelajaran yang bisa menumbuhkan minat dan motivasi bagi peserta didik dan menggunakan media pembelajaran yang bervariasi dan inovatif sehingga proses belajar mengajar menjadi lebih menyenangkan. Media pembelajaran ada bermacammacam yang dapat digunakan dalam pembelajaran yaitu media bagan, diagram, grafis, poster, kartun, komik, media gambar dan media diorama.

Media gambar adalah adalah media visual dalam bentuk grafis. Media grafis didefinisikan sebagai media yang mengkombinasikan fakta dan gagasan secara jelas dan kuat melalui suatu kombinasi pengungkapan kata-kata dan gambar-gambar. (Sudjana 2007). Sedangkan diorama adalah sebuah pemandangan tiga dimensi mini yang bertujuan untuk menggambarkan pemandangan yang sebenarnya. Diorama biasanya terdiri atas bentukbentuk sosok atau objek-objek ditempatkan di pentas yang berlatar belakang lukisan yang disesuaikan dengan penyajian. (Rodhatul Jennah 2009:85).

Karakteristik media ini adalah wujud dari pemandangan dan atau lingkungan serta isinya sama persis dengan bentuk kecilnya. Sehingga ketika sedang melihat lingkungan sawah 
misalnya, diorama harus memperhatikan detail pemandangan tersebut. Adapun kelemahan dari media diorama yaitu : 1) tidak dapat menjangkau sasaran dalam jumlah besar, 2) tidak dapat menampilkan unsur gerak dalam tampilannya. 3) membutuhkan kreativitas guru dan peserta didik, 4) dalam pembuatan membutuhkan waktu dan biaya. Sedangkan kelebihan dari media diorama ialah sebagai berikut : 1) dapat menggambarkan peristiwa yang terjadi disuatu tempat, waktu tertentu yang dilihat dari posisi atau arah tertentu pula secara lebih hidup, 2) dapat memberikan pemandangan atau gambaran visual dari pokok materi pelajaran yang sebenarnya dalam bentuk ukuran yang lebih kecil, 3) membawa ke dalam kelas sebagian kecil dari pada dunia dalam bentuk diperkecil dan tiga dimensi, dan 4) design yang menarik dapat memberikan keindahan dan menarik perhatian, serta memotivasi pengguna untuk mendapatkan pengalaman belajar yang lebih.

Berdasarkan penjelasan yang dipaparkan maka peneliti ingin mengkaji secara mendalam mengenai kombinasi media diorama dan media gambar dalam pembelajaran IPA, sehingga akan diketahui apakah akan berpengaruh pada hasil belajar peserta didik atau sebaliknya, yaitu melalui Penelitian Tindakan Kelas (PTK) yang berjudul "Kombinasi Media Diorama dan Media Gambar Pada SDN 5 Langkai Palangkaraya Tahun Pelajaran 2015/2016.

\section{METODE PENELITIAN}

Dalam pelaksanaannya peneliti menggunakan pendekatan penelitian Tindakan Kelas (PTK).Menurut Kunandar (2012 : 45) menjelaskan "PTK adalah penelitian tindakan yang dilakukan dengan tujuan memperbaiki mutu praktik pembelajaran di kelas. Fokus PTK pada peserta didik atau PBM yang terjadi di kelas". Kehadiran dan peran peneliti adalah sebagai peneliti dan pengajar. Peneliti adalah orang yang menyadari adanya permasalahan dalam proses belajar mengajar di kelas, sedangkan peran peneliti sebagai pengajar yaitu membuat Rancangan Pelaksanaan Pembelajaran (RPP) sekaligus penyampai bahan ajar selama pembelajaran. Di samping itu peneliti juga sebagai pengamat yang mengumpulkan dan menganalisis data serta sebagai pelapor hasil penelitian.

Dalam pelaksanaan penelitian tindakan kelas ini yang menjadi subjek penelitian adalah peserta didik kelas IV yang berjumlah 21 orang. Terdiri dari 7 peserta didik perempuan dan 14 peserta didik laki-laki. Sedangkan yang menjadi objek penelitian adalah hasil belajar IPA.

Pengumpulan data yang diperoleh pada penelitian ini dilakukan melalui pengamatan (observasi) dan tes hasil belajar. Data yang dikumpulkan dari setiap kegiatan yang dilaksanakan dalam siklus PTK dianalisis secara deskriptif dengan menggunakan teknik analisis kualitatif yang digunakan oleh peneliti untuk menjawab permasalahan. Anailisis kualitatif dilakukan untuk memperoleh kesimpulan masalah yang 
diteliti dari awal peneliti hingga akhir penelitian.

Data kualitatif diperoleh dari aktivitas terhadap peneliti dan aktivitas terhadap peserta didik dan respon peserta didik selama proses belajar rmengajar dengan menganalisis hasil belajar yang dilihat dalam proses belajar mengajar menggunakan kombinasi media diorama dan media gambar.

Data kuantitatif berasal dari hasil tes yang diberikan pada setiap akhir siklus kegiatan. Hal ini dilakukan untuk mengetahui peningkatan hasil belajar peserta didik pada pendekatan yang diterapkan.

\section{HASIL DAN PEMBAHASAN}

Data dari hasil penelitian ini berupa: 1) pengamatan aktivitas guru dan peserta didik 2) hasil belajar IPA menggunakan kombinasi media diorama dan media gambar

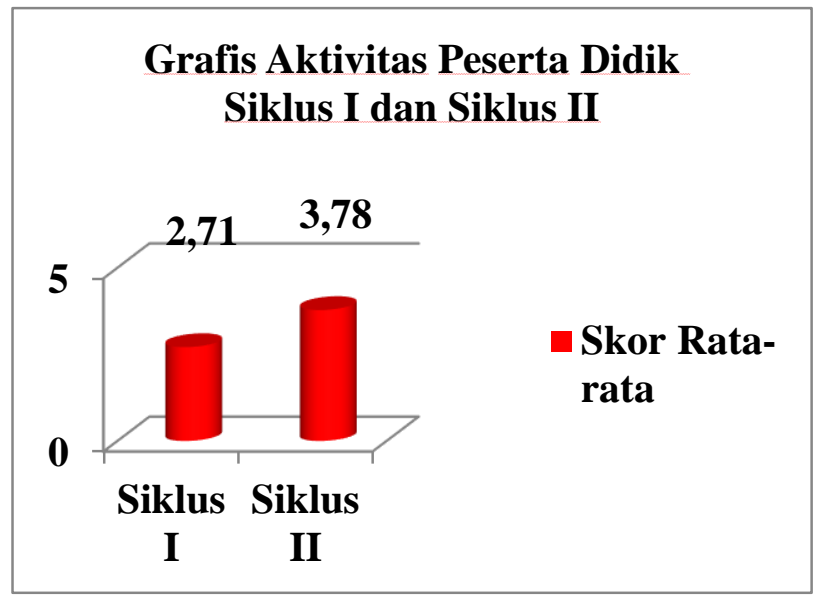

\section{Gambar 1}

Grafik Aktivitas Peserta Didik Pada

Pembelajaran Siklus I dan Siklus II

Berdasarkan tabel dan grafik tersebut maka dapat diketahui bahwa aktivitas belajar peserta didik mengalami peningkatan disetiap siklusnya. Berdasarkan analisis data yang dilakukan terhadap aktivitas peserta didik maka dapat diperoleh hasil aktivitas peserta didik pada setiap siklusnya. Pada Siklus I, aktivitas peserta didik memperoleh skor rata-rata 2,71 dengan kriteria cukup. Pada Siklus II aktivitas peserta didik memperoleh skor rata-rata 3,78 dengan kriteria baik.

Hal tersebut menunjukkan bahwa penggunaan kombinasi media diorama dan media gambar dapat digunakan dan tepat agar peserta didik aktif dalam proses pembelajaran.

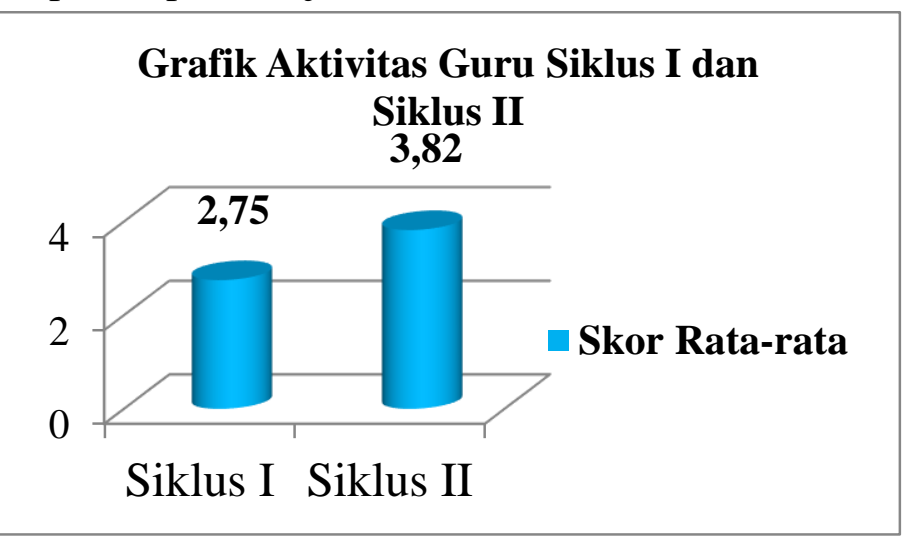

\section{Gambar 2}

Grafik Aktivitas Guru Pada

Pembelajaran Siklus I dan Siklus II

Berdasarkan tabel dan grafik diatas dapat diketahui bahwa aktivitas guru juga mengalami peningkatan pada setiap siklusnya. Hal ini menunjukkan bahwa guru melakukan perbaikan pada setiap siklusnya berdasarkan hasil refleksi.

Hasil belajar IPA peserta didik menggunakan kombinasi media diorama dan media gambar 


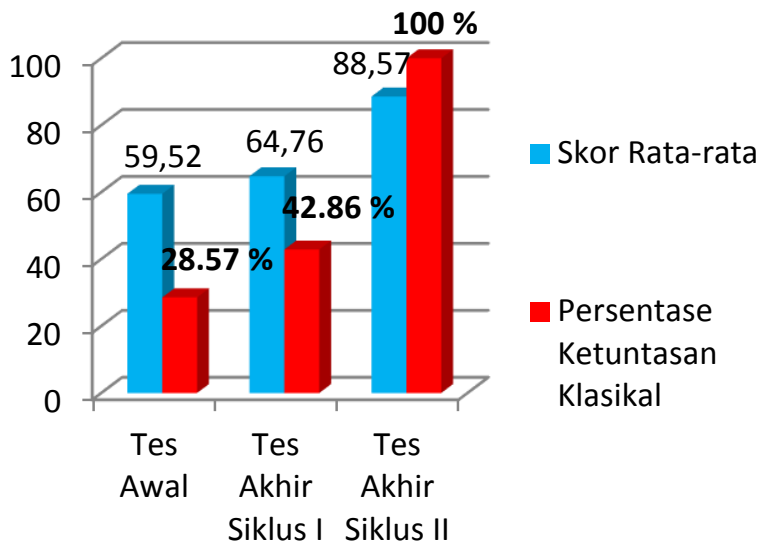

Gambar 3

Grafik persentase siklus I dan siklus II

Berdasarkan analisis data yang dilakukan terhadap hasil belajar peserta didik, maka pada tes awal, hasil belajar peserta didik memperoleh nilai rata-rata 59,52 (dibawah $\mathrm{KKM} \geq 65$ ) dengan ketuntasan klasikal 28,57\% dengan kriteria tidak tercapai. Pada Siklus I hasil belajar peserta didik memperoleh nilai rata-rata 64,76 dengan ketuntasan klasikal 42,86\% dengan kriteria kurang tercapai. Pada Siklus II meningkat hasil belajar peserta didik memperoleh nilai rata-rata 88,57 dengan ketuntasan klasikal $100 \%$ dengan kriteria tercapai.

\section{SIMPULAN}

Berdasarkan hasil penelitian, maka dapat disimpulkan beberapa hal sebagai berikut Peserta didik kelas IV SDN 5 Langkail ebih aktif dan menyenangkan pada saat pembelajaran IPA dengan menggunakan kombinasi media diorama dan media gambar. Pada Siklus I, aktivitas peserta didik memperoleh skor rata-rata 2,71 dengan kriteria cukup. Pada Siklus II, skor ratarata aktivitas yang diperoleh peserta didik adalah 3,78 dengan kriteria baik.Penggunaan kombinasi media diorama dan media gambar pada pembelajaran IPA melibatkan peserta didik secara aktif dalam proses pembelajaran.

Ada peningkatan hasil belajar IPA peserta didik kelas IVSDN 5 Langkaipada saat pembelajaran IPA dengan menggunakan kombinasi media diorama dan media gambar. Pada tes awal, hasil belajar peserta didik memperoleh nilai rata-rata 59,52 (dibawah nilai $\mathrm{KKM} \geq 65$ ) dengan ketuntasan klasikal 28,57\% dengan kriteria tidak tercapai.

Pada Siklus I hasil belajar peserta didik memperoleh nilai rata-rata 64,76 dengan ketuntasan klasikal 42,86\% dengan kriteria kurang tercapai. Siklus II hasil belajar peserta didik memperoleh nilai rata-rata 88,57 dengan ketuntasan klasikal 100\% dengan kriteria tercapai.

\section{DAFTAR PUSTAKA}

Jennah, Rodhatul. 2009. Media Pembelajaran. Banjarmasin: AshShaff.

Kunandar. 2012. Langkah Mudah Penelitian Tindakan Kelas Sebagai Pengembangan Profesi Guru. Depok: PT Rajagrafindo Persada.

Sudjana, Nana. 2007. Media Pengajaran. Bandung: Sinar Baru Algensindo. 